\title{
PENGARUH RASIO ARUS KAS TERHADAP PREDIKSI KONDISI FINANCIAL DISTRESS PADA PERUSAHAAN JASA SEKTOR KEUANGAN YANG TERDAFTAR DI BURSA EFEK INDONESIA
}

\author{
ROMASI LUMBAN GAOL ${ }^{1}$
}

LAU RENSIA RIRI INDRIANI ${ }^{2}$

${ }^{1,2}$ Program Studi Akuntansi Fakultas Ekonomi Universitas Katolik Santo Thomas

${ }^{1}$ E-mail : romasilumbangaol@yahoo.co.id

${ }^{2}$ E-mail : laurensiagirsang4@gmail.com

\begin{abstract}
Abstrak
Penelitian ini bertujuan untuk menganalisis pengaruh rasio arus kas terhadap prediksi kondisi financial distress pada perusahaan jasa sektor keuangan sub sektor lembaga pembiayaanyang terdaftar di Bursa Efek Indonesia periode tahun 2011-2015. Data dari penelitian ini diperoleh dari laporan keuangan perusahaan jasa sektor keuangan sub sektor lembaga pembiayaan yang diambil dari www.idx.co.id dan Saham Oke tanggal 1 juni 2018. Penentuan sampel menggunakan metode purposive sampling. Teknik analisis data yang digunakan dalam penelitian ini adalah analisis regresi logistik dan pengujian hipotesis menggunakan uji t (parsial) dan uji f (simultan) dengan tingkat signifikansi 5\%.Hasil penelitianmenunjukkan bahwa rasio arus kas dari aktivitas operasi, rasio arus kas dari aktivitas investasi, dan rasio arus kas dari aktivitas pendanaan secara parsial tidak berpengaruh terhadap prediksi kondisi financial distress. Secara simultan menunjukkan bahwa rasio arus kas dari aktivitas operasi, rasio arus kas dari aktivitas investasi, dan rasio arus kas dari aktivitas pendanaan berpengaruh terhadap prediksikondisi financial distress pada perusahaan jasa sektor keuangan sub sektor lembaga pembiayaan.
\end{abstract}

Kata kunci: Rasio Arus Kas dari Aktivitas Operasi, Investasi, dan Pendanaan,Financial Distress

\section{PENDAHULUAN}

Kebangkrutan perusahaan dapat terjadi karena perusahaan mengalami masalah keuangan yang dibiarkan berlarut-larut. Beberapa perusahaan yang mengalami masalah keuangan mencoba mengatasi masalah tersebut dengan melakukan pinjaman dan penggabungan usaha. Sebelum kebangkrutan atau kegagalan perusahaan akan mengalami kondisi financial distress.

Ketidaksiapan perusahaan dalam memprediksi financial distress merupakan salah satu penyebab terjadinya kebangkrutan perusahaan. Kondisi financial distress merupakan kondisi dimana keuangan perusahaan dalam keadaan tidak sehat atau krisis. Financial distress yang cukup 
mengganggu kegiatan operasional perusahaan merupakan suatu kondisi yang perlu untuk diwaspadai dan diantisipasi.

Menurut Atika (2013) gejala awal terjadinya financial distress adalah ketika suatu perusahaan mengalami kesulitan untuk memenuhi kewajibannya. Kesulitan keuangan terjadi ketika perusahaan tidak dapat memenuhi jadwal pembayaran hutang atau ketika proyeksi arus kas mengindikasikan bahwa perusahaan tersebut akan segera tidak dapat memenuhi kewajibannya (Fachrudin, 2008). Indikator kesulitan keuangan dapat dilihat dari analisis aliran kas, analisis strategi perusahaan, dan laporan keuangan perusahaan.

Aliran kas dapat dilihat dari laporan arus kas. Laporan arus kas merupakan laporan yang memberikan informasi yang relevan mengenai penerimaan dan pengeluaran kas dalam periode waktu tertentu.

Informasi arus kas dibutuhkan pihak kreditor untuk mengetahui kemampuan perusahaan dalam pembayaran hutangnya. Apabila arus kas suatu perusahaan jumlahnya besar, maka pihak investor dan kreditor mendapatkan keyakinan atas pengembalian kredit yang diberikan. Jika arus kas suatu perusahaan bernilai kecil, maka pihak investor dan kreditor tidak mendapatkan keyakinan atas kemampuan perusahaan dalam membayar hutang.

Jika arus kas perusahaan mengalami penurunan secara terus menerus, para investor dan kreditor tidak akan mempercayakan kreditnya kembali kepada perusahaan karena perusahaan dianggap akan mengalami permasalahan keuangan atau financial distress. Dengan demikian, maka arus kas dapat dijadikan indikator untuk mengetahui kondisi keuangan perusahaan dalam memprediksi financial distress. Hal ini diperkuat oleh pendapat Alimilia dan Kristijadi (2003), yang menyatakan apabila rasio arus kas meningkat maka laba perusahaan akan meningkat dan hal ini akan meningkatkan nilai perusahaan sehingga kemungkinan perusahaan mengalami financial distress menjadi lebih kecil.

Dari uraian tersebut peneliti ingin membuktikan apakah rasio arus kas dengan mengunakan alat ukur Operating Cash Index Ratio; Cash Flow From Operation/Current Liabilities; Asset efficiency ratio; Investment in plant, property, and equipment/plant, property, and equipment; Investment in plant, property, and equipment/Total use of fund; Debt investment/total source of fund; Net debt/Total source of fund. dapat digunakan untuk memprediksi kondisi financial distress pada perusahaan jasa sektor keuangan sub sektor lembaga pembiayaan yang terdaftar di Bursa EfekIndonesia periode tahun 2011-2015?" 


\section{KAJIAN LITERATUR \\ Financial Distress}

Financial distress atau kesulitan keuanganmerupakan kondisi yang terjadi dimana perusahaan mengalami penurunan kondisi keuangan selama beberapa periode. Keadaan ini terjadi saat kondisi arus kas perusahaan pada beberapa periode tidak sesuai dengan arus kas yang diharapkan atau proyeksikan. Pada kondisi financial distress, kondisi cashflow sangat minimum sehingga menyebabkan terjadinya deadweight losses. Berarti, financial distress berada antara keadaan solvent dan insolvent (Pranowo, 2010).

Menurut Atmini (2005), financial distress adalah suatu konsep luas yang terdiri dari beberapa situasi dimana suatu perusahaan menghadapi masalah kesulitan keuangan. McCue (1991) mendefinisikan financial distress sebagai arus kas negatif,sedangkan Purwanti (2005) menyimpulkan bahwa financial distress adalah suatu situasi dimana arus kas operasi perusahaan tidak memadai untuk melunasi kewajibankewajiban lancar (seperti hutang dagang atau beban bunga) dan perusahaanterpaksa melakukan tindakan perbankan.

Hery (2017) menjelaskan indikator untuk melihat kondisi terjadinya financial distress menggunakan Interest Coverage Ratio (ICR). ICR menunjukkan sejauh mana atau berapa kali kemampuan perusahaan dalam membayar bunga. Kemampuan perusahaan di sini diukur dari jumlah laba sebelum bunga dan pajak. ICR dihitung sebagai hasil bagi antara laba sebelum bunga dan pajak dengan besarnya beban bunga yang harus dibayarkan. Dengan demikian, kemampuan perusahaan untuk membayar bunga pinjaman tidak dipengaruhi oleh pajak.Hery(2017)menyatakan, indikator untuk mengukur financial distress adalah:

$$
\text { interestcoverageratio }=\frac{\text { Laba sebelum bunga dan pajak }}{\text { Beban Bunga }}
$$

\section{Arus Kas}

Laporan arus kas merupakan salah satu laporan keuangan utama selain laporan laba/rugi dan neraca. Laporan arus kas melaporkan transaksi-transaksi atau kejadian-kejadian selama periode tertentu dari segi pengaruhnya terhadap kas. Laporan arus kas adalah laporan sumber dan penggunaan kas (cash flow statement) disusun untuk menunjukkan perubahan kas selama satu periode dan memberikan alasan mengenai 
perubahan kas tersebut dengan menunjukkan dari mana sumber-sumber kas dan penggunaannya (Jumingan, 2006).

Laporan arus kas memberikan informasi mengenai arus kas suatu perusahaan. Tujuan utama laporan arus kas adalah menyediakan informasi yang relevan mengenai penerimaan dan pembayaran kas sebuah perusahaan selama suatu periode.

Informasi arus kas berguna untuk menilai kemampuan perusahaan dalam menghasilkan kas dan setara kas dan memungkinkan para pemakai mengembangkan model untuk menilai dan membandingkan nilai sekarang dari arus kas masa depan (future cash flows) dari berbagai perusahaan.Informasi arus kas historis sering digunakan sebagai indikator dari jumlah, waktu, dan kepastian arus kas masa depan. Disamping itu, informasi arus kas juga berguna untuk meneliti kecermatan dari taksiran arus kas masa depan yang telah dibuat sebelumnya dan dalam menentukan hubungan antara profitabilitas dan arus kas bersih serta dampak perubahan harga.

\section{Operating Cash Index Ratio}

Mariana (2015) menjelaskan, operating cash index ratio merupakan kemampuan perusahaan untuk menghasilkan kas internal dari operasi yang sedang berjalan. Rasio ini membantu investor dan kreditor saat ini atau potensial dalam mengevaluasi "kualitas" dari laba perusahaan. Rasio ini memberikan indikasi yang lebih realistis dari tingkat penyimpangan antara arus kas operasi dan laba yang dilaporkan.

Hery (2017) menjelaskan rasio ini menunjukkan seberapa jauh penyesuaian dan asumsi akuntansi akrual mempengaruhi perhitungan laba bersih. Rumus untuk menghitung operating cash index ratio adalah:

$$
\text { Operatingcashindexratio }=\frac{\text { Arus Kas Bersih dari Aktivitas Operasi }}{\text { Net Income }}
$$

\section{Cash Flow From Operation / Current Liabilities}

Mariana (2015) menyimpulkan, kemampuan perusahaan dalam memenuhi kewajiban lancar. Rasio ini memberikan indikasi kemampuan perusahaan untuk membayar hutang dan kewajiban yang jatuh tempo dalam satu tahun. Dengan demikian, saat ini rasio cakupan kewajiban adalah pengukuran likuiditas berdasarkan perbandingan arus kas operasi dengan waktu jatuh tempo suatu kewajiban. 
Apabila suatu perusahaan tidak cukup menghasilkan kas dari operasi untukmemenuhi kewajibannya, diperlukan sumber pendanaan lain yang mungkin meningkatkan risiko default atau kebangkrutan. Dengan demikian, semakin tinggi rasio ini, kemungkinan perusahaan mengalami financial distress semakin rendah.

Hery (2017) menyimpulkan, rasio ini menunjukkan kemampuan arus kas operasi perusahaan dalam melunasi kewajiban lancarnya. Rumus untuk menghitung Cash FlowFrom Operation/Current Liabilities adalah:

$$
C F F O / C L=\frac{\text { Arus Kas Bersih dari Akivitas Operasi }}{\text { Hutang Lancar }}
$$

\section{Assets Efficiency Ratio}

Menurut Mariana (2015), assets efficiency ratio merupakan kemampuan arus kas bersih dari aktivitas operasi dalam menghasilkan total aset perusahaan. Rasio ini memberikan indikasi seberapa baik aset perusahaan dimanfaatkan untuk menghasilkan kembali arus kas. Secara umum, semakin tinggi rasio, semakin besar efisiensi penggunaan aset dan posisi keuangan perusahaan yang lebih baik. Dengan demikian, semakin tinggi asset efficiency ratio, maka semakin rendah kemungkinan perusahaan mengalami financial distress.

Indikator untuk mengukur asset efficiency ratio menurut Juwita (2009) adalah:

$$
\text { Assetefficiencyratio }=\frac{\text { Arus Kas Bersih dari Aktivitas Operasi }}{\text { Total Aset }}
$$

Investment in Plant, Property, and Equipment / Plant, Property, and Equipment

Menurut Mariana (2015), Rasio ini merupakan perbandingan besarnya investasi aktiva tetap dengan total aktiva tetap yangdimiliki oleh perusahaan. Rasio ini menunjukkan seberapa besar perusahaan mampu melakukan investasi dalam bentuk aktiva tetap. Dalam Koedestani et.al (2011) diperoleh hasil penelitian bahwa arus kas investasi yang negatif dapat digunakan untuk memprediksi financialdistress perusahaan, dimana arus kas investasi yangnegatif menunjukkan perusahaan yang sehat.

Juwita (2009) menyimpulkan, indikator untuk menghitung investment in plant, property, and equipment/plant, property, and equipment adalah: 


$$
I P P E / P P E=\frac{\text { Investasi Aktiva Tetap }}{\text { Aktiva Tetap }}
$$

\section{Investment in Plant, Property, and Equipment / Total Use of Fund}

Menurut Mariana (2015), Rasio ini merupakan perbandingan antara investasi aktiva tetap dengantotal penggunaan dana. Rumus untuk menghitung perbandingan investasi aktiva tetap dengan total penggunaan dana adalah (Juwita, 2009):

$$
I P P E / T U=\frac{\text { Investasi Aktiva Tetap }}{\text { Total Penggunaan Dana }}
$$

\section{Debt Investment / Total Source of Fund}

Menurut Mariana (2015), debt investment/total source of fund merupakan perbandingan antara perolehan hutang dengan total sumber dana. Semakin rendah rasio ini, maka semakin tinggi probabilitas perusahaan mengalami financial distress. Hal ini disebabkan karena perolehan hutang yang diperoleh perusahaan tidak diimbangi dengan total sumber dana perusahaan sehingga kemungkinan perusahaan mengalami masalah keuangan.

MenurutJuwita(2009), indikator untuk menghitung debt investment/ total source of fund adalah:

$$
D I / T S=\frac{\text { Perolehan Hutang }}{\text { Total Sumber Dana }}
$$

\section{Net Debt / Total Source of Fund}

Menurut Mariana (2015), net debt/total source of fund merupakan perbandingan antara hutang bersih dengan total sumber dana perusahaan. Net Debt sering digunakan sebagai ukuran bagi para investor untuk mengetahui posisi hutang sebenarnya. Net Debt dihitung dengan rumus short term liabilities+long term liabilities - cash and cash equivalent.

Indikator untuk mengukurnet debt/total source of fundadalah (Juwita, 2009) :

$$
N D / T S=\frac{\text { Perolehan Hutang }- \text { Pembayaran Hutang }}{\text { Total Sumber Dana }}
$$


Teori penagaruh Rasio Arus Kas dari Aktivitas Operasi Terhadap Prediksi Terjadinya Financial Distress

Aktivitas operasi merupakan hal yang vital bagi suatu perusahaan. Aktivitas operasi merupakan inti dari perusahaan dan merupakan alasan utama mengapa perusahaan tetap eksis di dunia perekonomian. Karena arus kas dari aktivitas operasi merupakan kegiatan penghasil utama bagi suatu perusahaan, perusahaan bisa saja bangkrut apabila tidak mampu memperoleh kas dari kegiatan operasi perusahaan untuk membiayai kewajibanny. Dalam penelitian Koedestani at all (2011), apabila perusahaan dalam kondisi arus kas dari aktivitas operasi yang negatif, arus kas dari aktivitas investasi dan pendanaan yang positif, maka kemungkinan perusahaansedang mengalami kondisi financial distress lebih besar daripada kemungkinan perusahaan tetap dalam kondisi yang sehat.Berdasarkan analisis di atas, maka dapat disimpulkan bahwa rasio arus kas dari aktivitas operasi berpengaruh terhadap prediksi terjadinya financial distress.

\section{Teori Pengaruh Rasio Arus Kas dari Aktivitas Investasi Terhadap Prediksi Terjadinya Financial Distress}

Selain aktivitas operasi yang menjadi titik fokus dalam laporan arus kas, aktivitas investasi dalam suatu perusahaan juga merupakan hal yang menjadi perhatian dalam memprediksi terjadinya financial distress. Aktivitas perusahaan tidak luput dari kegitan investasi terutama pada aset tetap yang digunakan untuk mendukung kegiatan operasional perusahaan. Walaupun laporan arus kas perusahaan dari aktivitas investasi bernilai negatif, kemungkinan perusahaan dalam kondisi sehat lebih besar daripada kemungkinan perusahaan mengalami financialdistress dengan syarat aliran kas dari aktivitas operasi dan pendanaanperusahaan bernilai positif (Koedestani, 2011).Berdasarkan analisis di atas, dapat disimpulkan bahwa rasio arus kas dari aktivitas investasi berpengaruh terhadap prediksi terjadinya financial distress.

\section{Teori Pengaruh Rasio Arus Kas dari Aktivitas Pendanaan Terhadap Prediksi Terjadinya Financial Distress}

Apabila perusahaan menghadapi kesulitan keuangan, tidak dapat dipungkiri jika perusahaan melakukan pembiayaan perusahaan dari pihak lain seperti pinjaman. Walaupun perusahaan sedang mengalami cash inflow yang negatif dari aktivitas operasi, dengan memperolehpembiayaan melalui pinjaman, manajemen perusahaan akan melakukan investasi 
dalam beberapa peluang yang ada. Namun, dikarenakan tingkat leverage yang cukup tinggi dan kewajiban untuk membayar pokokpinjaman beserta bunganya, perusahaan akan menghadapi tantangan dalam keuangannya yang akhirnya membawa perusahaan menghadapi kondisi financial distress.Berdasarkan analisis diatas, dapat disimpulkan bahwa rasio arus kas dari aktivitas pendanaan berpengaruh terhadap prediksi terjadinya financial distress.

\section{Hipotesis Penelitian} berikut:

Berdasarkan analisis di atas, maka hipotesisnya adalah sebagai

$$
\begin{aligned}
\mathrm{H}_{1 \mathrm{a}}= & \begin{array}{l}
\text { Operating cash index ratio berpengaruh secara parsial } \\
\text { terhadap prediksi terjadinya financial distress }
\end{array} \\
\mathrm{H}_{1 \mathrm{~b}}= & \text { Cash Flow From Operation/Current Liabilities berpengaruh } \\
& \text { secara parsial terhadap prediksi terjadinya financial distress } \\
\mathrm{H}_{1 \mathrm{c}}= & \begin{array}{l}
\text { Assets efficiency ratio berpengaruh secara parsial terhadap } \\
\text { prediksi terjadinya financial distress }
\end{array} \\
\mathrm{H}_{2 \mathrm{a}}= & \begin{array}{l}
\text { Investment in Plant, Property, and Equipment/Plant, Property, } \\
\text { and Equipment berpengaruh secara parsial terhadap prediksi }
\end{array} \\
& \text { terjadinya financial distress } \\
\mathrm{H}_{2 \mathrm{~b}}= & \text { Investment in Plant, Property, and Equipment/Total Source of } \\
& \text { Fundberpengaruh secara parsial terhadap prediksi terjadinya } \\
& \text { financial distress } \\
\mathrm{H}_{3 \mathrm{a}}= & \text { Debt Investment/Total Source of Fund berpengaruh secara } \\
& \text { parsial terhadap prediksi terjadinya financial distress } \\
\mathrm{H}_{3 \mathrm{~b}}= & \text { Net Debt/Total Source of Fundberpengaruh secara parsial } \\
& \text { terhadap prediksi terjadinya financial distress } \\
\mathrm{H}_{4}= & \begin{array}{l}
\text { Rasio arus kas dari aktivitas operasi, aktivitas investasi, dan } \\
\text { aktivitas pendanaan berpengaruh secara simultan terhadap } \\
\text { prediksi terjadinya financialdistress }
\end{array}
\end{aligned}
$$

\section{METODE PENELITIAN}

\section{Populasi dan Sampel}

Populasi penelitian ini adalah perusahaan jasa sektor keuangan sub sektor lembaga pembiayaan yang laporan keuangannya terdapat di BEI periode 2011-2015. Sampel yang digunakan dalampenelitian iniditentukan dengan menggunakan metode purposive sampling, yaitu teknik penentuan 
sampel dengan pertimbangan tertentu Berdasarkan kriteria, jumlah sampel yang memenuhi untuk diteliti ada sebanyak 9 (sembilan) perusahaan dengan periode penelitian 5 (lima) tahun, sehingga jumlah sampel 45.

\section{Operasionalisasi Variabel}

a. Operating Cash Index Ratio(X1), Hery (2017) menjelaskan rasio ini menunjukkan seberapa jauh penyesuaian dan asumsi akuntansi akrual mempengaruhi perhitungan laba bersih.Rumus untuk menghitung operating cash index ratio adalah:

Arus Kas Bersih dari Aktivitas Operasi

Net Income

b. Cash FlowFrom Operation/Current Liabilities (X2), Hery (2017) menyimpulkan, rasio ini menunjukkan kemampuan arus kas operasi perusahaan dalam melunasi kewajiban lancarnya. Rumus untuk menghitung Cash FlowFrom Operation/Current Liabilities adalah: ArusKasBersihdariAktivitasOperasi

\section{Hutang Lancar}

c. Asset efficiency ratio(X3), merupakan kemampuan arus kas bersih dari aktivitas operasi dalam menghasilkan total aset perusahaan. Rasio ini memberikan indikasi seberapa baik aset perusahaan dimanfaatkan untuk menghasilkan kembali arus kas.Asset efficiency ratiodihitung dengan menggunakan rumus sebagai berikut:

\section{Arus Kas Bersih dari Aktivitas Operasi}

Total Aset

d. Investment in plant, property, and equipment/plant, property, and equipment (X4), merupakan perbandingan besarnya investasi aktiva tetap dengan total aktiva tetap yang dimiliki oleh perusahaan. Rasio ini menunjukkan seberapa besar perusahaan mampu melakukan investasi dalam bentuk aktiva tetap.Investment in plant, property, and equipment/plant, property, and equipmentdihitung dengan menggunakan rumus sebagai berikut:

\section{Investasi Aktiva Tetap}

Aktiva Tetap 
e. Investment in plant, property, and equipment/Total use of fund (X5), merupakan perbandingan antara investasi aktiva tetap dengantotal penggunaan dana.Investment in plant, property, and equipment/Total use of funddihitung dengan menggunakan rumus sebagai berikut:

$$
\frac{\text { Investasi Aktiva Tetap }}{\text { Total Penggunaan Dana }}
$$

f. Debt investment/total source of fund (X6), merupakan perbandingan antara perolehan hutang dengan total sumber dana. Semakin rendah rasio ini, maka semakin tinggi probabilitas perusahaan mengalami financial distress.Debt investment/total source of funddihitung dengan menggunakan rumus sebagai berikut:

$$
\frac{\text { Perolehan Hutang }}{\text { Total Sumber Dana }}
$$

g. Net debt/Total source of fund (X7), merupakan perbandingan antara hutang bersih dengan total sumber dana perusahaan. Net Debt sering digunakan sebagai ukuran bagi para investor untuk mengetahui posisi hutang sebenarnya.Net debt/Total source of funddihitung dengan menggunakan rumus sebagai berikut:

$$
\text { Perolehan Hutang - Pembayaran Hutang }
$$

Total Sumber Dana

h. Financial distress(Y), merupakan kondisi yang terjadi dimana perusahaan mengalami penurunan kondisi keuangan selama beberapa periode.Financial distressdiukur dengan menggunakan rumus sebagai berikut:

$$
I C R=\frac{\text { Laba sebelum bunga dan pajak }}{\text { Beban Bunga }}
$$

\section{Teknik Analisis Data}

Alat analisis yang digunakan dalam penelitian adalah analisis regresi logistik, yaitu untuk menguji apakah probabilitas perusahaan mengalami Financial Distressdapat diprediksi olehOperating Cash Index Ratio;Cash Flow From Operation/Current Liabilities; Asset efficiency ratio;Investment in plant, property, and equipment/plant, property, and 
equipment; Investment in plant, property, and equipment/Total use of fund; Debt investment/total source of fund; Net debt/Total source of fund.

Model regresi logistik yang digunakan untuk menguji hipotesis pada penelitian ini yaitu:

$$
\ln \frac{\mathrm{P}}{1-\mathrm{P}}=\mathrm{a}+\mathrm{b}_{1} \mathrm{X}_{1}+\mathrm{b}_{2} \mathrm{X}_{2}+\mathrm{b}_{3} \mathrm{X}_{3}+\mathrm{b}_{4} \mathrm{X}_{4}+\mathrm{b}_{5} \mathrm{X}_{5}+\mathrm{b}_{6} \mathrm{X}_{6}+\mathrm{b}_{7} \mathrm{X}_{7}+\mathrm{e}
$$

$\operatorname{Ln}(\mathrm{P} / 1-\mathrm{P}) \quad=$ Probabilitas perusahaan mengalami financial distress

a $\quad=$ Konstanta

$\mathrm{X}_{1} \quad=\mathrm{CFFO} / \mathrm{NI}$

$\mathrm{X}_{2} \quad=\mathrm{CFFO} / \mathrm{CL}$

$\mathrm{X}_{3} \quad=\mathrm{CFFO} / \mathrm{TA}$

$\mathrm{X}_{4} \quad=$ IPPE/PPE

$\mathrm{X}_{5} \quad=\mathrm{IPPE} / \mathrm{TU}$

$\mathrm{X}_{6} \quad=\mathrm{DI} / \mathrm{TS}$

$\mathrm{X}_{7} \quad=\mathrm{ND} / \mathrm{TS}$

$\mathrm{b}_{1}-\mathrm{b}_{7} \quad=$ Koefisien regresi

e $\quad=$ error

\section{HASIL PENELITIAN DAN PEMBAHASAN}

\section{Analisis Statistik Deskriptif}

Statistik deskriptif memberikan gambaran atau deskripsi suatu dana yang dilihat dari nilai rata-rata (mean), standar deviasi, nilai maksimum, dan nilai minimum dari variabel-variabel independen dan variabel dependen. Berikut ini data statistik secara umum dari seluruh data yang digunakan.

Tabel. 1

Descriptive Statistic

\begin{tabular}{|l|l|r|r|r|r|}
\hline & $\mathrm{N}$ & \multicolumn{1}{|c|}{ Minimum } & Maximum & \multicolumn{1}{c|}{ Mean } & Std. Deviation \\
\hline CFFO_NI & 45 & $-18,7331$ & 86,3280 &,- 861609 & 14,8439657 \\
CFFO_CL & 45 &,- 7946 & 2,1915 &,- 064218 &, 4399999 \\
CFFO_TA & 45 &,- 5866 &, 3266 &,- 074442 &, 1821898 \\
IPPE_PPE & 45 &,- 8019 &,- 0514 &,- 362169 &, 1959862 \\
IPPE_TU & 45 &,- 0241 &,- 0001 &,- 007047 &, 0058861 \\
DI_TS & 45 &, 0937 &, 8882 &, 671918 &, 1810931 \\
ND_TS & 45 &,- 0020 &, 8484 &, 632333 &, 1865665 \\
Valid N & 45 & & & & \\
(listwise) & & & & & \\
\hline
\end{tabular}

Sumber : Data Sekunder Diolah 2018 
Dari tabel 1 dapat dijelaskan :

a. Variabel Operating Cash Index Ratio (CFFO/NI) memiliki nilai minimum -18,7331, dan memiliki nilai maksimum 86,3280, dengan nilai mean -0,861609 dan standar deviation sebesar 14,8439657.

b. Variabel Cash Flow from Operation/ Current Liabilities (CFFO/CL) memiliki nilai minimum -0,7946, dan nilai maksimum 2,1915, dengan nilai mean -0,064218 dan standar deviation sebesar 0,4399999 .

c. Variabel Assets Efficiency Ratio (CFFO/TA) memiliki nilai minimum $-0,5866$, dan nilai maksimum 0,3266 , dengan nilai mean $-0,074442$ danstandar deviation sebesar 0,1821898.

d. Variabel Investment in Plant, Property, and Equipment/ Plant, Property, and Equipment (IPPE/PPE) memiliki nilai minimum 0,8019, dan nilai maksimum -0,0514 dengan nilai mean $-0,362169$ dan standar deviationsebesar 0,1959862.

e. Variabel Investment in Plant, Property, and Equipment/ Total Use of Fund (IPPE/TU) memiliki nilai minimum -0,0241, dan nilai maksimum -0,0001 dengan nilai mean -0,007047 dan standar deviation sebesar 0,0058861 .

f. Variabel Debt Investment/ Total Source of Fund (DI/TS) memiliki nilai minimum 0,0937 , dan nilai maksimum 0,8882 dengan nilai mean 0,671918 dan standar deviation sebesar 0,1810931.

g. Variabel Net Debt/ Total Source of Fund (ND/TS) memiliki nilai minimum $-0,0020$, dan nilai maksimum 0,8484 dengan nilai mean 0,632333 dan standar deviation sebesar 0,1865665 .

\section{Uji Model}

a. Uji Kelayakan Model (Goodness of Fit)

Uji kelayakan ini dilakukan dengan menggunakan goodness of fit test yang diukur dengan melihat signifikansi pada tabel Hosmer and Lemeshow. Berikut ini hasil uji Hosmer andLemeshow's Goodness of Fit Test

Tabel. 2

Hosmer and Lemeshow Test

\begin{tabular}{|l|r|r|c|}
\hline Step & Chi-square & Df & Sig. \\
\hline 1 & 10,381 & &, 168 \\
\hline
\end{tabular}

Sumber : Data sekunder diolah 2018 
Dari tabel di atas dapat dilihat bahwa nilai chi-square dari penelitian ini adalah 10,381 dan nilai signifikansi dari penelitian ini adalah 0,168 di mana nilai chi-square tabel adalah $14,067(10,381<14,067)$. Dengan demikian, maka nilai chi-square hitung lebih kecil dari nilai chisquare tabel dan nilai signifikansi penelitian ini lebih besar dari 0,05 $(0,168>0,05)$ yang berarti model dapat diterima dan layak digunakan untuk penelitian ini.

\section{b. Uji Keseluruhan Model}

Uji keseluruhan model digunakan untuk melihat model yang telah dihipotesiskan telah fit atau tidak dengan data. Pengujian dilakukan dengan membandingkan nilai antara -2 Log Likelihood pada awal (block number $=0$ ) di mana model hanya memasukkan konstanta dengan nilai -2 Log Likelihood pada akhir (block number=1) di mana model sudah memasukkan konstanta dan variabel bebas.nilai -2 log likelihood pada awal adalah 57,286 sedangkan nilai -2 log likelihood pada akhir, setelah dimasukkan konstanta dan variabel bebas adalah 36,136. Penurunan nilai 2 log likelihood menunjukkan bahwa model penelitian ini baik atau dengan kata lain fit dengan data, artinya penambahan-penambahan variabel bebas yaitu rasio arus kaske dalam model penelitian akan memperbaiki model fit dalam penelitian ini.

\section{c. Koefisien Determinasi (Nagelkerke R Square)}

Tabel. 3

Model Summary

\begin{tabular}{|c|c|c|c|}
\hline Step & -2 Log likelihood & Cox \& Snell R Square & Nagelkerke R Square \\
\hline 1 & $36,136^{\mathrm{a}}$ &, 375 &, 521 \\
\hline
\end{tabular}

a. Estimation terminated at iteration number 6 because parameter estimates changed by less than ,001.

Sumber : Data sekunder diolah 2018

Berdasarkan tabel di atas, nilai statistik Nagelkerke $R$ Square sebesar 0,521 yang berarti variabel dependen, yaitu financial distress dapat dijelaskan oleh variabel independen, yaitu rasio arus kassebesar 52,1\% dan sisanya 47,9\% dapat dijelaskan oleh variabel lain di luar model. Berdasarkan nilai Nagelkerke tersebut dapat dikatakan bahwa variabel 
rasio arus kas dapat digunakan untuk memprediksi kondisi financial distress perusahaan.

\section{d. Matriks Klasifikasi}

Kekuatan prediksi dari model regresi untuk memprediksi kemungkinan perusahaan mengalami financial distress adalah sebesar $86,7 \%$. Hal ini menunjukkan bahwa dari 30 sampel perusahaan yang mengalami financial distress, sebanyak 26 perusahaan yang diprediksi tepat mengalami financial distress dan sebanyak 4 perusahaan yang diprediksi tidak mengalami financial distress. Kekuatan prediksi dari model regresi untuk memprediksi kemungkinan perusahaan tidak mengalami financial distress adalah sebesar $66,7 \%$. Hal ini menunjukkan bahwa dari 15 sampel perusahaan yang tidak mengalami financial distress, 10 perusahaan yang diprediksi tepat tidak mengalami financial distress dan sebanyak 5 perusahaan yang diprediksi tidak tepat. Keakuratan prediksi secara menyeluruh sebesar $80 \%$. Tingginya persentase ketepatan pada tabel klasifikasi tersebut mendukung tidak adanya perbedaan yang signifikan terhadap data hasil prediksi dan data observasinya yang menunjukkan sebagai model regresi logistik yang baik.

\section{Pengujian Hipotesis}

Pengujian hipotesis menggunakan model logistic regression binary pada tingkat signifikan 5\%. Hasil pengolahan data menunjukkan sebagai berikut.

Tabel. 4

Variables in the Equation

\begin{tabular}{|c|c|c|c|c|c|c|c|}
\hline & & B & S.E. & Wald & df & Sig. & $\operatorname{Exp}(B)$ \\
\hline \multirow[t]{8}{*}{ Step $1^{a}$} & CFFO_NI &, 029 &, 041 &, 514 & 1 & ,474 & 1,030 \\
\hline & CFFO_CL &,- 638 & 2,898 & ,048 & 1 & ,826 & ,528 \\
\hline & CFFO_TA & $-4,498$ & 6,004 &, 561 & 1 & ,454 & ,011 \\
\hline & IPPE_PPE & 2,881 & 2,818 & 1,045 & 1 & ,307 & 17,835 \\
\hline & IPPE_TU & $-11,922$ & 77,592 &, 024 & 1 & 878 & ,000 \\
\hline & DI_TS & $-3,009$ & 10,909 & ,076 & 1 & ,783 & ,049 \\
\hline & ND_TS & $-9,592$ & 11,035 & ,756 & 1 & ,385 & ,000 \\
\hline & Constant & 7,642 & 2,797 & 7,466 & 1 & ,006 & 2084,840 \\
\hline
\end{tabular}

a. Variable(s) entered on step 1: CFFO_NI, CFFO_CL, CFFO_TA, IPPE_PPE, IPPE_TU, DI_TS, ND_TS.

Sumber : Data sekunder diolah 2018 
Dari pengujian persamaan regresi logistik tersebut, maka diperoleh model regresi logistik sebagai berikut:

$\ln \frac{\mathrm{P}}{1-\mathrm{P}}=7,642+0,029 \mathrm{X}_{1}-0,638 \mathrm{X}_{2}-4,498 \mathrm{X}_{3}+2,881 \mathrm{X}_{4}-11,9227 \mathrm{X}_{5}-3,009 \mathrm{X}_{6}-$ $9,592 \mathrm{X}_{7}$

\section{a. Hipotesis I}

Dari tabel 4 dapat dilihat nilai signifikansi rasio arus kas dari aktivitas operasi dengan variabel Operating cash index ratio, Cash Flow From Operation/Current Liabilities, dan Assets efficiency ratio adalah 0.474, 0.826 , dan 0.454 . Hal ini menunjukkan bahwa nilai tersebut berada di atas nilai alpa, yaitu $0,05(0.474>0,05 ; 0.826>0,05 ; 0.454>0,05)$. Hal ini menunjukkan bahwa probabilitas terjadinya finansial distress tidak dapat diprediksi oleh Operating cash index ratio, Cash Flow From Operation/Current Liabilities, dan Assets efficiency ratio pada perusahaan jasa sektor keuangan sub sektor lembaga pembiayaan. Hal ini berarti menolak hipotesis $\mathrm{Ha}_{\mathrm{b} 1}, \mathrm{Ha}_{\mathrm{b} 2}$, dan $\mathrm{Ha}_{\mathrm{b} 3}$.

\section{b. Hipotesis II}

Dari tabel 4 dapat dilihat nilai signifikansi rasio arus kas dari aktivitas investasi dengan variabel Investment in Plant, Property, and Equipment/Plant, Property, and Equipment dan Investment in Plant, Property, and Equipment/Total Use of Fund adalah 0,307 dan 0,878. Hal ini menunjukkan bahwa nilai tersebut berada di atas nilai alpa, yaitu 0,05 $(0,307>0,05$ dan $0,878>0,05)$. Dengan demikian, bahwa probabilitas terjadinya finansial distress tidak diprediksi oleh Investment in Plant, Property, and Equipment/Plant, Property, and Equipment dan Investment in Plant, Property, and Equipment/Total Use of Fund pada perusahaan jasa sektor keuangan sub sektor lembaga pembiayaan. Hal ini berarti menolak hipotesis $\mathrm{Ha}_{\mathrm{b} 4}$ dan $\mathrm{Ha}_{\mathrm{b} 5}$.

\section{c. Hipotesis III}

Dari tabel 4 dapat dilihat nilai signifikansi rasio arus kas dari aktivitas pendanaan dengan variabel Debt Investment/Total Source of Fund dan Net Debt/Total Source of Fund adalah 0,783 dan 0,385. Hal ini menunjukkan bahwa nilai tersebut berada di atas nilai alpa, yaitu $0,05(0,783>0,05$ dan $0,385>0,05)$. Dengan demikian bahwa probabilitas terjadinya finansial distress tidak dapat diprediksi oleh Debt Investment/Total Source of Fund dan Net Debt/Total Source of Fund pada perusahaan jasa sektor keuangan 
sub sektor lembaga pembiayaan. Hal ini berarti menolak hipotesis $\mathrm{Ha}_{\mathrm{b} 6}$ dan $\mathrm{Ha}_{\mathrm{b} 7}$.

\section{Pengujian Signifikan Model Secara Simultan}

Tabel. 5

\section{Omnibus Tests of Model Coefficients}

\begin{tabular}{|ll|r|r|r|}
\hline & & Chi-square & Df & \multicolumn{1}{|c|}{ Sig. } \\
\hline Step 1 & Step & 21,151 & 7 &, 004 \\
& Block & 21,151 & 7 &, 004 \\
& Model & 21,151 & 7 &, 004 \\
\hline
\end{tabular}

Sumber : Data sekunder diolah 2018

Dari tabel di atas, dapat diketahui bahwa nilai signifikansi sebesar 0,004 . Hasil nilai signifikansi tersebut lebih kecil dari $0,05(0,004<0,05)$ dan nilai chi-square hitung lebih besar dari nilai chi-square tabel $(21,151>$ 14,067), maka dapat disimpulkan bahwa profabilitas teradinya Financial Distess secara bersama sama dapat dipridiksi oleh Operating Cash Index Ratio, Cash Flow From Operation/Current Liabilities, Assets Efficiency Ratio, Investment in Plant, Property, and Equipment/Plant, Property, and Equipment, Investment in Plant, Property, and Equipment/Total Use of Fund, Debt Investment/Total Source of Fund dan Net Debt/Total Source of Fund. pada perusahaan jasa sektor keuangan sub sektor lembaga pembiayaan yang terdapat di Bursa Efek Indonesia.

\section{Pembahasan}

a. Pengaruh Operating cash index ratio terhadap prediksi terjadinya financial distress

Hasil uji regresi logistik terhadap variabel operating cash index ratio menunjukkan nilai koefisien positif sebesar 0,029 dengan nilai signifikansi 0,474 lebih besar dari 0,05 . Hal ini berarti operating cash index ratio tidak berpengaruh terhadap prediksi kondisi financial distress. Bahwa hasil penelitian ini berlawanan dengan teori yang menyatakan bahwa ketika operating cash index ratio turun maka akan terjadi financial distress.

Namun, hasil penelitian ini sesuai dengan data yang ada di perusahaan jasa sektor keuangan sub sektor lembaga pembiayaan bahwa ada beberapa perusahaan yang mengalami penurunanoperating cash index ratio tetapi perusahaan tersebut tidak mengalamifinancial distress. 
Misalnya perusahaan BFI Finance Indonesia Tbk (BFIN), perusahaan ini tidak mengalami financial distress tetapi operating cash index ratio mengalami penurunan sebesar -1,1011 ditahun 2014.

Sementara itu, terdapat pula beberapa perusahaan yang mengalami peningkatanoperating cash index ratio tetapi perusahaan tersebut mengalamifinancial distress. Misalnya perusahaan Verena Multi Finance Tbk (VRNA), perusahaan ini tergolong mengalami financial distress tetapi mengalami peningkatan operating cash index ratio sebesar 86,3280 ditahun 2015.

\section{b. Pengaruh Cash flow from operation/current liabilities terhadap prediksi terjadinya financial distress}

Hasil uji regresi logistik terhadap variabel cash flow from operation/current liabilities menunjukkan nilai koefisien negatif sebesar 0,638 dengan nilai signifikansi 0,826 yang lebih besar dari 0,05 . Hal ini berarti rasio cash flow from operation/current liabilities tidak berpengaruh terhadap prediksi kondisi financial distress. Bahwa hasil penelitian ini berlawanan dengan teori yang menyatakan bahwa ketika rasio cash flow from operation/current liabilities turun maka akan terjadi financial distress.

Namun, hasil penelitian ini sesuai dengan data yang ada di perusahaan jasa sektor keuangan sub sektor lembaga pembiayaan bahwa ada beberapa perusahaan yang mengalami penurunan rasio cash flow from operation/current liabilities tetapi perusahaan tersebut tidak mengalamifinancial distress. Misalnya perusahaan BFI Finance Indonesia Tbk (BFIN), perusahaan ini tidak mengalami financial distress tetapi rasiocash flow from operation/current liabilities mengalami penurunan sebesar -0,2703 ditahun 2013.

Sementara itu, terdapat pula beberapa perusahaan yang mengalami peningkatan rasio cash flow from operation/current liabilities tetapi perusahaan tersebut mengalamifinancial distress. Misalnya perusahaan Tifa Finance Tbk (TIFA), perusahaan ini tergolong mengalami financial distress tetapi mengalami peningkatan rasiocash flow from operation/current liabilities sebesar 0,3073 ditahun 2013. 
c. Pengaruh Assets efficiency ratio terhadap prediksi terjadinya financial distress

Hasil uji regresi logistik terhadap variabel assets efficiency ratio menunjukkan nilai koefisien negatif sebesar $-4,498$ dengan nilai signifikansi 0,454 yang lebih besar dari 0,05. Hal ini berarti assets efficiency ratio tidak berpengaruh terhadap prediksi kondisi financial distress. Bahwa hasil penelitian ini berlawanan dengan teori yang menyatakan bahwa ketika assets efficiency ratio turun maka akan terjadi financial distress.

Namun, hasil penelitian ini sesuai dengan data yang ada di perusahaan jasa sektor keuangan sub sektor lembaga pembiayaan bahwa ada beberapa perusahaan yang mengalami penurunan assets efficiency ratio tetapi perusahaan tersebut tidak mengalami financial distress. Misalnya perusahaan Clipan Finance Indonesia Tbk (CFIN), perusahaan ini tidak mengalami financial distress tetapi rasio assets efficiency ratio mengalami penurunan sebesar -0,1254 ditahun 2013.

Sementara itu, terdapat pula beberapa perusahaan yang mengalami peningkatan assets efficiency ratio tetapi perusahaan tersebut mengalami financial distress. Misalnya perusahaan Buana Finance Tbk (BBLD), perusahaan ini tergolong mengalami financial distress tetapi mengalami peningkatanassets efficiency ratio sebesar 0,1601 ditahun 2015.

Secara keseluruhan, rasio arus kas dari aktivitas operasi yaitu Operating cash index ratio, Cash Flow From Operation/Current Liabilities, dan Assets efficiency ratio tidak berpengaruh secara signifikan terhadap kemungkinan perusahaan mengalami financial distress dalam ukuran interest coverage ratio karena nilai signifikansi ketiga variabel tersebut lebih besar dari 0,05. Hasil penelitian ini sejalan dengan penelitian terdahulu yang dilakukan oleh Fitria (2010), Djongkang dan Rita (2014), dan Aminah (2015) yang menyatakan bahwa arus kas dari aktivitas operasi tidak berpengaruh terhadap financial distress karena semakin besar arus kas dari aktivitas operasi maka semakin besar ketertarikan para investor untuk melakukan investasi maka akan semakin mudah perusahaan membiayai kegiatan operasi.

d. Pengaruh Investment in Plant, Property, and Equipment/Plant, Property, and Equipment terhadap prediksi terjadinya financial distress

Hasil uji regresi logistik terhadap variabel Investment in Plant, Property, and Equipment/Plant, Property, and Equipment menunjukkan 
nilai koefisien positif sebesar 2,881 dengan nilai signifikansi 0,307 yang lebih besar dari 0,05. Hal ini berarti rasio Investment in Plant, Property, and Equipment/Plant, Property, and Equipment tidak berpengaruh terhadap prediksi kondisi financial distress. Tanda koefisien yang positif dapat diinterpretasikan bahwa semakin tinggi rasio Investment in Plant, Property, and Equipment/Plant, Property, and Equipment, semakin tinggi kemungkinan perusahaan mengalami financial distress. Bahwa hasil penelitian ini berlawanan dengan teori yang menyatakan bahwa ketika rasio Investment in Plant, Property, and Equipment/Plant, Property, and Equipment turun maka akan terjadi financial distress.

Namun, hasil penelitian ini sesuai dengan data yang ada di perusahaan jasa sektor keuangan sub sektor lembaga pembiayaan bahwa ada beberapa perusahaan yang mengalami penurunanrasio Investment in Plant, Property, and Equipment/Plant, Property, and Equipment tetapi perusahaan tersebut tidak mengalami financial distress. Misalnya perusahaan Clipan Finance Indonesia Tbk (CFIN), perusahaan ini tidak mengalami financial distress tetapi rasio Investment in Plant, Property, and Equipment/Plant, Property, and Equipment mengalami penurunan sebesar -0,5665 ditahun 2014.

\section{e. Pengaruh Investment in Plant, Property, and Equipment/Total} Use of Fund terhadap prediksi terjadinya financial distress

Hasil uji regresi logistik terhadap variabel Investment in Plant, Property, and Equipment/Total Use of Fund menunjukkan nilai koefisien negatif sebesar $-11,922$ dengan nilai signifikansi 0,878 yang lebih besar dari 0,05. Hal ini berarti rasio Investment in Plant, Property, and Equipment/Total Use of Fund tidak berpengaruh terhadap prediksi kondisi financial distress. Tanda koefisien yang negatif dapat diinterpretasikan bahwa semakin rendah rasio ini, semakin tinggi kemungkinan terjadinya financial distress. Bahwa hasil penelitian ini berlawanan dengan teori yang menyatakan bahwa ketika Investment in Plant, Property, and Equipment/Total Use of Fund turun maka akan terjadi financial distress.

Namun, hasil penelitian ini sesuai dengan data yang ada di perusahaan jasa sektor keuangan sub sektor lembaga pembiayaan bahwa ada beberapa perusahaan yang mengalami penurunanrasioInvestment in Plant, Property, and Equipment/Total Use of Fund tetapi perusahaan tersebut tidak mengalamifinancial distress. Misalnya perusahaan BFI 
Finance Indonesia Tbk (BFIN), perusahaan ini tidak mengalami financial distress tetapi rasioInvestment in Plant, Property, and Equipment/Total Use of Fund mengalami penurunan sebesar -0,0184 ditahun 2013.

Secara keseluruhan, rasio arus kas dari aktivitas investasi yaitu Investment in Plant, Property, and Equipment/Plant, Property, and Equipment dan Investment in Plant, Property, and Equipment/Total Use of Fund tidak berpengaruh secara signifikan terhadap kemungkinan perusahaan mengalami financial distresskarena nilai signifikansi kedua variabel tersebut lebih besar dari 0,05.

\section{f. Pengaruh Debt Investment/Total Source of Fund terhadap prediksi terjadinya financial distress}

Hasil uji regresi logistik terhadap variabel Debt investment/Total source of fund menunjukkan nilai koefisien negatif sebesar -3,009 dengan nilai signifikansi 0,783 yang lebih besar dari 0,05. Hal ini berarti rasio Debt investment/Total source of fund tidak berpengaruh terhadap prediksi kondisi financial distress. Tanda koefisien negatif dapat diinterpretasikan bahwa semakin rendah rasio ini, semakin tinggi kemungkinan terjadinya financial distress. Rasio Debt investment/Total source of fund yang rendah mengindikasikan bahwa sumber dana perusahaan kemungkinan didanai melalui debt investment sehingga perusahaan kemungkinan mengalami kesulitan dalam membayar perolehan hutangnya pada saat jatuh tempo. Bahwa hasil penelitian ini berlawanan dengan teori yang menyatakan bahwa ketika Debt investment/Total source of fund turun maka akan terjadi financial distress.

Namun, hasil penelitian ini sesuai dengan data yang ada di perusahaan jasa sektor keuangan sub sektor lembaga pembiayaan bahwa ada beberapa perusahaan yang mengalami peningkatanrasio Debt investment/Total source of fund tetapi perusahaan tersebut mengalami financial distress. Misalnya perusahaan Adira Dinamika Multi Finance Tbk (ADMF), perusahaan ini tergolong mengalami financial distress tetapi mengalami peningkatan rasioDebt investment/Total source of fund sebesar 0,8641 ditahun 2014. 


\section{g. Pengaruh Net Debt/Total Source of Fund terhadap prediksi terjadinya financial distress}

Hasil uji regresi logistik terhadap variabel Net debt/Total source of fund menunjukkan nilai koefisien negatif sebesar -9,592 dengan nilai signifikansi 0,385 yang lebih besar dari 0,05. Hal ini berarti rasio Net debt/Total source of fund tidak berpengaruh terhadap prediksi kondisi financial distress. Tanda koefisien yang negatif dapat diinterpretasikan bahwa semakin rendah rasio ini, semakin tinggi kemungkinan terjadinya financial distress. Bahwa hasil penelitian ini berlawanan dengan teori yang menyatakan bahwa ketika Net debt/Total source of fund turun maka akan terjadi financial distress.

Namun, hasil penelitian ini sesuai dengan data yang ada di perusahaan jasa sektor keuangan sub sektor lembaga pembiayaan bahwa ada beberapa perusahaan yang mengalami peningkatanrasio Net debt/Total source of fund tetapi perusahaan tersebut mengalami financial distress. Misalnya perusahaan Radana Bhaskara Finance Tbk (HDFA), perusahaan ini tergolong mengalami financial distress tetapi mengalami peningkatan rasio Net debt/Total source of fund sebesar 0,8463 ditahun 2013.

Secara keseluruhan, rasio arus kas dari aktivitas pendanaan yaitu Debt investment/Total source of fund dan Net debt/Total source of fund tidak berpengaruh secara signifikan terhadap kemungkinan perusahaan mengalami financial distress karena nilai signifikansi kedua variabel tersebut lebih besar dari 0,05 .

\section{KESIMPULAN DANSARAN}

\section{Kesimpulan}

a. Variabel rasio arus kas dari aktivitas operasi (Operating Cash Index Ratio, Cash Flow From Operation/Current Liabilities, dan Assets Efficiency Ratio) secara parsial tidak berpengaruh terhadap prediksi kondisi financial distress pada perusahaan jasa sektor keuangan sub sektor lembaga pembiayaan yang terdaftar di Bursa Efek Indonesia.

b. Variabel rasio arus kas dari aktivitas investasi (Investment in Plant, Property, and Equipment/Plant, Property, and Equipment dan Investment in Plant, Property, and Equipment/Total Use of Fund) secara parsial tidak berpengaruh terhadap prediksi kondisi financial 
distress pada perusahaan jasa sektor keuangan sub sektor lembaga pembiayaan yang terdaftar di Bursa Efek Indonesia.

c. Variabel rasio arus kas dari aktivitas pendanaan (Debt Investment/Total Source of Fund dan Net Debt/Total Source of Fund) secara parsial tidak berpengaruh terhadap prediksi kondisi financial distress pada perusahaan jasa sektor keuangan sub sektor lembaga pembiayaan yang terdaftar di Bursa Efek Indonesia.

d. Variabel rasio arus kas dari aktivitas operasi (Operating Cash Index Ratio, Cash Flow From Operation/Current Liabilities, dan Assets Efficiency Ratio), rasio arus kas dari aktivitas investasi (Investment in Plant, Property, and Equipment/Plant, Property, and Equipment dan Investment in Plant, Property, and Equipment/Total Use of Fund), dan rasio arus kas dari aktivitas pendanaan (Debt Investment/Total Source of Fund dan Net Debt/Total Source of Fund) secara simultan berpengaruh terhadap prediksi kondisi financial distress pada perusahaan jasa sektor keuangan sub sektor lembaga pembiayaan yang terdaftar di Bursa Efek Indonesia.

\section{Saran}

Bagi peneliti selanjutnya yang ingin melakukan penelitian yang sama, diharapkan peneliti menambah variabel independen lain yang memiliki kemungkinan untuk berpengaruh terhadap kondisi financial distress perusahaan dan menambah rentang waktu penelitian, memilih sampel perusahaan lain untuk membuktikan apakah hasil penelitian ini dapat digeneralisasikan pada perusahaan subsektor lainnya yang terdaftar di Bursa Efek Indonesia, dan menggunakan ukuran lain dalam mengkategorikan perusahaan yang mengalami financial distress selain menggunakan indikator interest coverage ratio.

\section{DAFTAR PUSTAKA}

Aminah, S. 2015. Manfaat Laba dan Arus Kas dalam Menentukan Prediksi Kondisi Financial Distress. Jurnal Akuntansi Vol 4 (5): 1-22.

Atika, Darminto, dan Handayani, Siti Ragil. 2012. Pengaruh Beberapa Rasio Keuangan Terhadap Prediksi Kondisi Financial distress 
(Studi Pada Perusahaan Tekstil Dan Garmen Yang Terdaftar Di Bursa Efek Indonesia Periode 2008-2011) Jurnal Ekonomi Bisnis dan Akuntansi, Vol 11, No.2.

Djongkang, F. dan Rita 2014. Manfaat Laba dan Arus Kas untuk Memprediksi Prediksi Kondisi Financial Distress. Jurnal Akuntansi Vol 1 (1).

Fachrudin, Khaira Amalia. 2008. Kesulitan Keuangan Perusahaan dan Personal. Medan: USU Press.

Fitria. 2010. Penggunaan Laba Dan Arus Kas Untuk Memprediksi Kondisi Financial Distress. Skripsi. Program Sarjana Fakultas Ekonomi Universitas Diponegoro. Semarang.

Ghozali, Imam. 2016. Aplikasi Analisis Multivariate dengan Program SPSS Edisi 8. Semarang: Universitas Diponegoro

Hery. 2016. Analisis Laporan Keuangan Integrated and Comprehensive Edition. Jakarta: PT. Grasindo

Hery.2017.Teori Akuntansi Pendekatan Konsep dan Analisis. Jakarta: PT.Grasindo

Jumingan. 2006. Analisis Laporan Keuangan, Bumi Aksara, Cetakan Pertama, Jakarta.

Juwita, A. (2009). Prediksi Rasio Keuangan Terhadap Kondisi Financial Distress pada Perusahaan Property yang Terdapat di Bursa Efek Indonesia. Skripsi. Universitas Sebelas Maret Surakarta.

Kordestani, Gholamreza, Vahid Bilgari, dan Mehrdad Bakhtiari. 2011. "Ability of Combinations of Cash Flow Components to Predict Financial Distress". Business: Theory and Practice, Volume 12, No.3. pp. 277-285.

Koes Pranowo. 2010. "Analisis Corporate Financial Distress Perusahaan Publik (Non Financial Companies)." Student Journal. Vol. 8

Mariana. 2015. Analisis Pengaruh Rasio Arus Kas Terhadap Prediksi Kondisi Financial Distress. Skripsi. Program Sarjana Fakultas Ekonomi dan Bisnis Universitas Sumatera Utara. 
McCue, M.J. 1991. The Use of Cash Flow to Analyze Financial Distress in California Hospitals. Hospital and Health Service Administration, 36: 223-241.

Purwanti, Yulia. 2005. Analisis Rasio Keuangan Dalam Memprediksi Financial Distresss pada Perusahaan Manufaktur yang Terdaftar di Bursa Efek Jakarta periode 1998-2003. Skripsi. Yogyakarta 